\title{
What are the barriers to agricultural biomass market development? The case of Poland
}

\author{
Sylwia Roszkowska ${ }^{1}$ (D) Natalia Szubska-Włodarczyk ${ }^{1}$
}

Accepted: 25 August 2021 / Published online: 3 September 2021

(C) The Author(s) 2021

\begin{abstract}
This paper examines the main determinants of biomass market development from a regional perspective in the context of current EU climate and energy policy. The EU's targeting of climate neutrality implies a new, multifaceted role for agriculture as a producer of energy resources. The challenge is to orient production to support the sustainable development of the circular economy. The possibility of using agricultural waste as a type of energy raw material aligns with a holistic approach to product management. The use of agricultural biomass as an energy raw material can enable increased energy self-sufficiency and reduced dependence on imported fuels among Poland's regions and an increase in the country's energy security. The aim of the study is to identify barriers to and opportunities for the development of the agricultural biomass market. The empirical section presents survey data from interviews with farm owners in the Polish province with the highest agricultural biomass potential, located in a region with one of the largest opencast mines in Europe. The estimated parameters of a logit model indicate that the logistical aspects of raw material collection and organization and a lack of knowledge of biomass are the main barriers to biomass development on the supply side.
\end{abstract}

Keywords Biomass supply $\cdot$ Energy resource $\cdot$ Renewable energy

JEL classification $\mathrm{N} 50 \cdot \mathrm{O} 13$

\section{Introduction}

In the face of global warming, actions supporting climate and energy policies are necessary. Intensive steps must be taken to reduce greenhouse gas emissions to prevent further temperature rises. EU climate policy targets aim to reduce greenhouse gas emissions to 20\% below their 1990 levels. To reach this objective, increasing renewable energy use is crucial (European Commission 2012). There is enough potential biomass in the EU to increase the share of this feedstock for heat, district heating, and the combined heat and power (CHP) sectors from 5.2 to 67.3 million toe (Panoutsou 2016). By sector, the largest $\mathrm{CO}_{2}$ emitters are energy and industry. Mandova et al. (2018) demonstrated that iron and steel plants in the EU could reduce their $\mathrm{CO}_{2}$ emissions

Sylwia Roszkowska

sylwia.roszkowska@uni.lodz.pl

1 Department of Economic Mechanisms, Faculty of Economics and Sociology, University of Lodz, 3/5 POW Street, 90-255 Lodz, Poland by $42 \%$ through biomass use. However, this forecast seems optimistic. Their research showed that biomass, including waste-based feedstock, has great potential but that there are also technical limitations. Giuntoli et al. (2016) indicated that the use of cereal straw and cattle slurry in EU power generation could help to mitigate global warming.

The increasing importance of renewable energy sources and the implementation of EU climate and energy policy influence the main pillars of agricultural policy at the local and regional levels. Today, agriculture, in addition to satisfying food, cultural and social needs, can play a significant role in meeting energy needs as a producer of raw materials and as a site of development for the renewable energy industry (for discussion see Bielski et al. 2021). Rural areas are an important source of renewable energies (i.e., water, wind, solar radiation, geothermal and biomass; for more on the classification of renewable energies, see Marks-Bielska et al. $2019,2020)$ and thus play a significant role in centralizing the energy transformation. Distributed energy is the future in the energy sector, and it seems that rural areas will be its foundation. 
An integrated approach to the development and management of agricultural renewable energy can contribute to the sustainable development of rural areas through the comprehensive use of biomass and supply of new generation fuels (Barbieri et al. 2013 or Igliński et al. 2015). The development of the bioenergy sector may positively affect employment not only in directly related sectors, namely, energy and agriculture, but also in indirectly associated sectors, particularly transport, trade, services, and manufacturing. Renewable energy sources may positively affect rural development by initiating creative thinking, entrepreneurship, and job creation. Calculations of the socioeconomic consequences of bioenergy produced from biomass showed that the multiplier effect could reach 2.44 , which confirms the socioeconomic benefits for the global economy (de la Rúa and Lechón 2016). Furthermore, the research of Goh et al. (2019) showed that the local use of biomass could increase energy security in rural areas.

On the other hand, the production of targeted crops, namely, energy crops, poses a threat connected with the possibility of crowding out areas assigned to food production (Roszkowski 2013; FAO 2010). In this regard, Choi et al. (2019) investigated the impact of bioeconomic development on the agricultural market in the EU and the world. Their study showed that using biomass supply for the bioenergy sector to realize goals such as reductions in greenhouse emissions resulted in an increase in food prices.

Rural development based on biomass production has been highlighted by Spinelli et al. (2018), who considered the gap created by dwindling firewood demand and showed that small-scale pellet and microchip production creates a real opportunity for forest owners. These additional biomass products are attractive because forest owners sell to final users. Siegmeier et al. (2015) analyzed the possibilities of energy production on a single farm from residue and waste biomass. In this way, organic farms can contribute to reducing greenhouse gas emissions from livestock manure and produce renewable energy. Moreover, this solution could increase farmers' income if they sell the additional product. Technical analysis has also confirmed the potential of agricultural biomass for energy production. Based on observations of field crop growth, Chang and Huang (2018) noted the high sustainable energy potential of hydrothermal carbonization of agricultural biomass waste. The study demonstrated an increase of up to $40 \%$ in field crop stem lengths, with fresh crop weights increasing $113 \%$. García-Torreiro et al. (2016) analyzed the biological pretreatment of different agricultural residues for second-generation bioethanol production, while Pinna-Hernández et al. (2019) conducted research on the use of agricultural biomass waste in Almería province (Spain) for thermal and electricity generation. The researchers analyzed four types of agricultural biomass waste within a radius of $100 \mathrm{~km}$ and, taking into account different economic criteria, found olive tree prunings to be the most efficient solution.

The empirical biomass literature has focused on, among other topics, organizational issues in the biomass sector, principles of sustainable international trade in biomass, risks and opportunities in the international biomass trade, and practical barriers to this trade. The main barriers are national or regional protectionist policies and trade tariffs, technical standards, logistics and different certification systems (see Altman et al. 2013; Pelkmans et al. 2019). On the other hand, a key principle articulated in this literature is the priority of the local use of biomass over trade. Although trade can enable the sustainable local use of biomass, research in this area is still limited for many transition countries, including Poland.

The biomass and bioenergy literature has also evaluated technological aspects of biomass processing. The research has estimated demand and analyzed the strategic use of biomass (see Bentsen and Felby 2012) and examined agrotechnical indicators of biomass as an energy raw material (Budzyński et al. 2015; Niedziółka et al. 2011) and issues regarding raw material transport (Ranta and Rinne 2006; Searcy et al. 2014). The papers on the subject have also provided analyses regarding the use of energy plants for energy production (see McKendry 2002, or Shen et al. 2015).

Meanwhile, Bórawski et al. (2019) analyzed the development of the renewable energy and biofuel market in the EU. According to their results, Poland is the third largest producer of ethanol and biodiesel (after Germany and France). This high potential confirms the significance of agricultural biomass in achieving EU sustainable development goals. For example, Florkowski et al. (2018) showed good prospects for the use of biowaste such as food waste in rural households as a cosubstrate to produce biogas for other locally available agricultural residues.

Furthermore, Poland has the second largest potential capacity (after Germany) to cofire biomass with coal. Research conducted by Cintas et al. (2018) showed that $70 \%$ of biomass demand for cofiring in 2020 - and $80 \%$ in 2030 — would come from Germany and Poland. In Poland, mainly forest biomass is used for cofiring. The study showed that while demand for biomass for cofiring is greater than that for domestic forest residue, total biomass supply (agriculture and forest residue) is greater than biomass demand for cofiring.

Zyadin et al. (2021) carried out a survey among 210 farmers from central (Toruń Province) and southern (Upper Silesia Province) Poland to investigate farmers' perceptions and opinions regarding the development of the biomass and bioenergy market. The results indicated that the farmers were not willing to switch to biocrop cultivation. Another study (see Zyadin et al. 2018) estimated surplus forest and agricultural biomass potential in the aforementioned provinces. 
The researchers assessed biomass agriculture potential at $0.60 \mathrm{t} / \mathrm{ha}$ over a 12 -month period. Moreover, the study indicated that $30 \%$ of biomass surplus could be used for energy generation. These findings point to a need to analyze the possibilities of developing the agricultural biomass market in Poland.

This study aims to identify the barriers to and opportunities for the development of the agricultural biomass market. Survey data for Lodz Province, the leading Polish province in terms of agricultural biomass potential, are used. Its agricultural biogas potential from animal production waste equals $6256.9 \mathrm{TJ}$, putting the region in fifth place out of the sixteen provinces in Poland (see SzubskaWłodarczyk 2018). Additionally, Poland's largest opencast mine (Bełchatów brown coal mine) - one of the largest opencast mines in Europe-operates in the Lodzkie region (for details, see Zawada 2018). Moreover, many different initiatives regarding support for renewable energy development are being undertaken in the province, including projects cofunded by the EU such as the "Bioenergy for the Region" Cluster (http://www.bioenergiadlaregionu.eu/en/).

To the authors' knowledge, this study is the first to identify barriers to the regional agricultural biomass market from farmers' perspective. This information is crucial for bioenergy and sustainable development in Poland. The findings of this study could support the design of policies to encourage agricultural biomass use.

\section{Data}

Before the data sources are introduced, it is important to indicate some features of the agricultural biomass market that seem to be imperfectly competitive. There are many reasons for the inefficiency of this market. It is assumed that the causes for the inefficiency of the market mechanism are inherently external. Access to information on biomass market functioning is incomplete. Hence, energy consumers do not have sufficient knowledge of the benefits of energy efficiency. From the perspective of agricultural biomass market organization, factors such as the flow of knowledge and information, financing sources, market infrastructure, and local and regional policy development through coordination of agricultural, energy and environmental policies are important. Moreover, one can observe considerable vertical integration in the organization of the biomass market, which is not fully conducive to technological development. This form of market organization gives rise to many questions: Should there be special requirements for production of agricultural biomass for energy feedstock? Are biomass processing technologies flexible enough to enable energy production without the need to incur major costs in adapting the technologies to the type, quality and quantity of biomass? The agricultural biomass market is monopsonistic, with the monopsonist buying biomass from farmers at a price below marginal cost and below the value of the marginal product of agricultural biomass. In contrast, in a competitive market, the marginal product of agricultural biomass would equal its price (see Winden et al. 2015; Li et al. 2018).

Taking into account the aforementioned considerations, this paper identifies the prospects for the development of regional agricultural biomass markets. Survey analyses were conducted using interviews with a representative group of farmers from Lodz Province. The study considers the main barriers to the development of regional agricultural biomass markets. Farmers' lack of access to information about the possibilities of using this raw material for energy and lack of knowledge about the biomass concept itself are considered. This ignorance regarding the management of agricultural production waste may concern mainly farms not typically focused on energy production. In addition, farmers may create and use biomass only for their own needs; this observation refers mainly to straw, which is often used as a fertilizer. However, other types of agricultural biomass (including manure, slurry, vegetable and fruit pomace, cut grass, and wood from pruned orchards) should also be considered as production waste. As agricultural biomass usually consists of raw material in large volumes, it seems reasonable to study the issue of transport to energy producers. Additionally, other issues concerning the biomass market are analyzed, namely, a lack of interest on the demand side, uncertainty about the stability of legal regulations and organizational determinants.

To analyze barriers to biomass market development, this study uses survey data. The CATI survey, based on a questionnaire addressed to farms with animal, crop, and mixed production, was carried out in 2014. Representativeness (at the regional level) of the data of farms with large agricultural land and high numbers of livestock was ensured. The minimum sample size was set at 280 farms. To ensure an adequate sample given possible survey nonresponse, the final sample included 364 farms.

The questionnaire consisted of two parts. The first part concerned the general characteristics of the farm. This part of the questionnaire sought to determine farmers' level of knowledge of agricultural biomass and interest in the production of energy crops. Farmers' answers were used to define the type, quantity and method of biomass use. The second part of the questionnaire included three sets of questions referring to ways of using agricultural biomass. The first set of questions was addressed to farmers who sold agricultural biomass. The second set was aimed at farmers who used it for their own energy needs, and the last set of questions was addressed to farmers who did not process biomass at all or use it in a previously undefined way. 


\section{Methods}

In-depth data from the aforementioned questionnaire survey and a logit model are used to examine this study's research question.

The dependent dummy variable is related to the following question: "Are you interested in the sale of agricultural biomass?" Definitions of the other variables included in the empirical model are provided in Table 1.

In the empirical model, the function has a logistic distribution (see Hosmer Jr. et al. 2013):

$p_{i}=\frac{\exp \left(\alpha_{0}+\alpha_{1} X_{i}\right)}{1+\exp \left(\alpha_{0}+\alpha_{1} X_{i}\right)}$,

where $p_{i}$ is the probability of the event that the farmer is interested in the sale of agricultural biomass $(\mathrm{Y}=1), \mathrm{X}_{\mathrm{i}}$ $(i=1, \ldots, 16)$ is the set of explanatory variables, and $\alpha$ represents the model parameters.

The model parameters are estimated using the maximum likelihood estimator. The odds ratios are calculated using the following formula:

$\frac{p_{i}}{1-p_{i}}=\exp \left(\alpha_{0}+\sum_{i=1}^{n} \alpha_{i} x_{i}\right)$

To assess goodness of fit, McFadden's pseudo- $\mathrm{R}^{2}$ is used:

$R_{\mathrm{McFadden}}^{2}=1-\frac{\ln \widehat{L_{U R}}}{\ln \widehat{L_{R}}}$

where $\ln \widehat{L_{U R}}$ is the log likelihood value for the fitted model and $\ln \widehat{L_{R}}$ is the log likelihood value for the null model, which includes only an intercept as a predictor.

\section{Discussion of results}

Most surveyed farmers (77\%) revealed that they know that agricultural biomass exists. At the same time, $69 \%$ of farmers admitted that the information about the opportunities to use agricultural energy are insufficient. Most respondents did not know where the nearest biomass heating plant or biogas plant was located. Nearly $86 \%$ of them declared that no one had offered to buy agricultural biomass from them.

Most respondents (94\%) stated that they used all the agricultural biomass generated on their farm only for their own needs, namely, as field manure, litter, livestock feed, or compost. Only a small group of respondents (13\%) reported that they sell agricultural biomass, while $4 \%$ of the farmers said that they use it for energy purposes and $2.5 \%$ left it unused.

The vast majority of respondents (83\%) indicated that they were not interested in energy crop cultivation. While some farmers $(15 \%)$ stated their willingness to cultivate this type of plant, only $3 \%$ actually do so.

The most common reasons for the lack of interest in cultivating energy crops were the unprofitability of sales or production (32\%), a lack of assurance regarding continued sales or collection (25\%), and others (34\%), with the last category including reasons related to a different farm profile, insufficient farm area, lack of knowledge about the issue, lack of sales, lack of interest from buyers, lack of knowledge about profitability and sales possibilities, demanding or difficult cultivation, soil that is too low or too high quality, and insufficient employment.

Turning to the main features of the surveyed farmers (see Table 2 for the main descriptive statistics of the analyzed variables), one can note that the average farm area was approximately 30.44 ha. The average respondent was not interested in the sale of agricultural biomass, nor did he or she want to deliver biomass to a collection point. The average respondent reported that no one had offered to buy his or her agricultural biomass for energy usage and did not know where the nearest biomass heating plant or biogas plant was. On the other hand, the average farmer was familiar with the concept of agricultural biomass. He or she was willing to deliver agricultural biomass to the collection point, albeit only within distances not longer than $40 \mathrm{~km}$. Due to the low number of observations on some variables (only 10-15\% of farmers answered the questions "What do you consider a satisfactory minimum price per ton of biomass?" and "Within what distance would you be willing to deliver agricultural biomass?"), the decision was made to eliminate variables X5 and $\mathrm{X} 7$ from further analyses.

Table 3 presents the correlation coefficients, namely, the phi coefficients (also known as the mean square contingency coefficient), suitable for nominal or binary categories. Some 


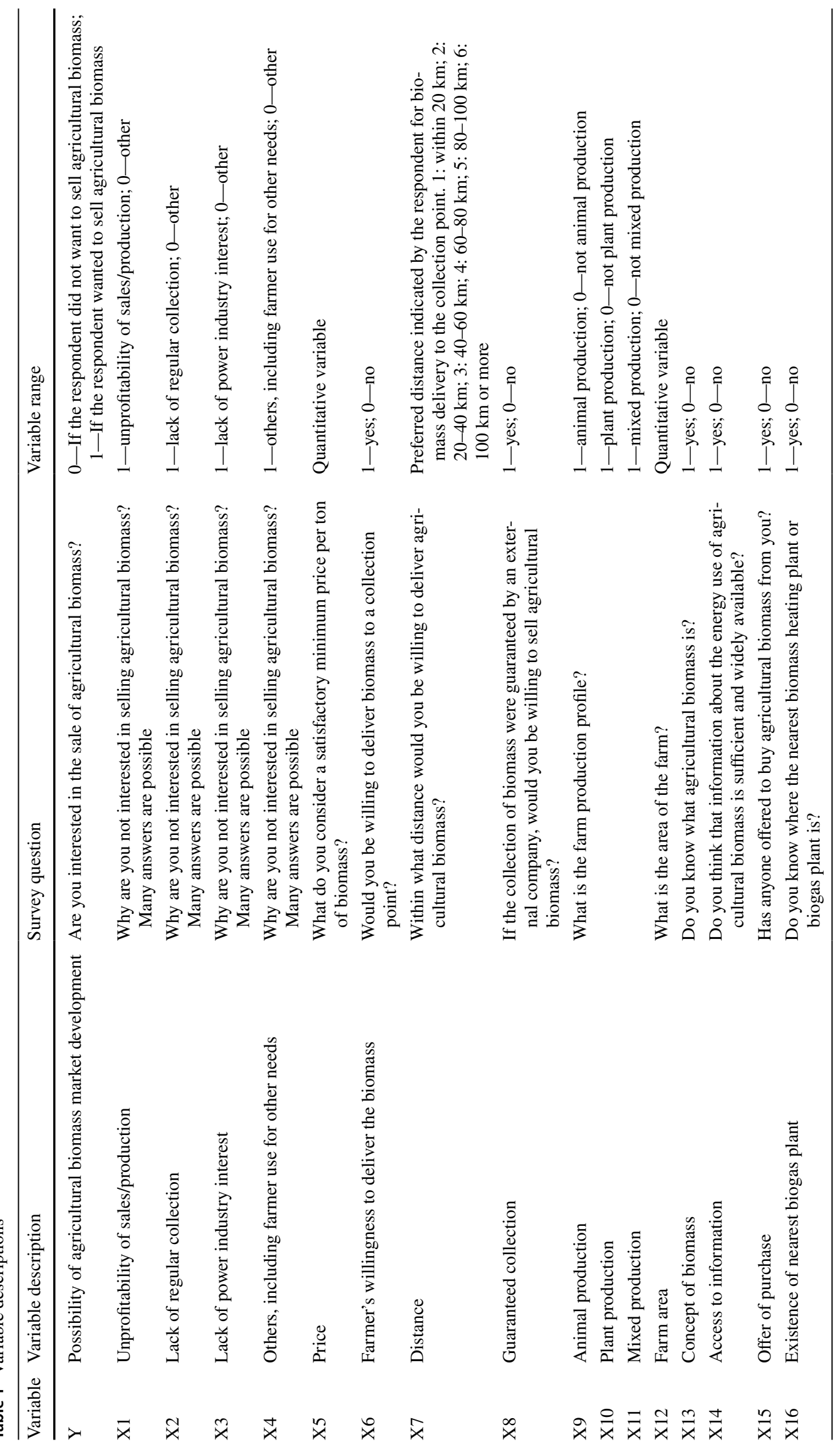


Table 2 Summary statistics

\begin{tabular}{llccc}
\hline Variable & Variable description & $\begin{array}{l}\text { No. of } \\
\text { observations }\end{array}$ & Mean & Std. dev \\
& & 244 & 0.25 & 0.43 \\
Y & Possibility of agricultural biomass market development & 244 & 0.29 & 0.45 \\
X1 & Unprofitability of sales/production & 244 & 0.14 & 0.35 \\
X2 & Lack of regular collection & 244 & 0.01 & 0.09 \\
X3 & Lack of power industry interest & 244 & 0.4 & 0.49 \\
X4 & Others, including farmer use for other needs & 40 & 178 & 63.1 \\
X5 & Price & 243 & 0.14 & 0.34 \\
X6 & Farmer's willingness to deliver biomass & 33 & 1.54 & 1.17 \\
X7 & Distance & 244 & 0.29 & 0.45 \\
X8 & Guaranteed collection & 243 & 0.35 & 0.48 \\
X9 & Animal production & 243 & 0.27 & 0.45 \\
X10 & Plant production & 243 & 0.35 & 0.48 \\
X11 & Mixed production & 244 & 30.44 & 36.64 \\
X12 & Farm area & 236 & 0.8 & 0.4 \\
X13 & Concept of biomass & 237 & 0.3 & 0.46 \\
X14 & Access to information & 241 & 0.11 & 0.32 \\
X15 & Offer of purchase & 238 & 0.15 & 0.36 \\
X16 & Existence of nearest biogas plant & &
\end{tabular}

interesting findings arise from an analysis of the results presented in the table. In terms of statistically significant coefficients, farmers who perceive biomass sales as unprofitable usually have some knowledge of the biomass market and indicate that all mentioned barriers are important. Interestingly, farmers using biomass for their own needs are eager to sell it under guaranteed collection circumstances. These conditions are not necessary for those who are willing to deliver it. Farmers' willingness to transport biomass is positively correlated with farm area. The surface size also matters for plant production specialization. On average, plant farmers are familiar with the concept of the biomass market and have received some business proposals concerning biomass sales.

The estimated correlation coefficients (see Table 3) also reveal some multicollinearity problems in the regression framework. Thus, as a first step of the analysis, the logit model parameters using one of X's as explanatory variables is estimated, and then in a second step, as many statistically significant explanatory variables as possible are included.

The preliminary results (see Table 4) show the irrelevance of variables defining the characteristics of agricultural holdings, particularly the farm production profile $(\mathrm{X} 9, \mathrm{X} 10, \mathrm{X} 11)$. In contrast, the production area (X12) matters for biomass supply, although the marginal effect is rather small (OR 1.017). Interestingly, most farmers were not able to indicate a minimum satisfactory price. Nevertheless, the price effect in the constrained subsample is statistically nonsignificant for biomass supply.

Moreover, the impact of variables determining farmers' knowledge of biomass (X13, X14, X16) is substantial and statistically significant in explaining farmers' interest in the sale of agricultural biomass. The estimated odds ratios suggest that actions promoting familiarity with the concept of biomass could result in supply growth.

The presented estimates indicate that the expected unprofitability of production (X1), lack of regular collection (X2) and use of biomass for other needs (X3) decrease farmers' willingness to deliver and sell agricultural biomass. The odds ratios of all these variables indicate a negative effect and are very high in terms of magnitude.

It seems that positive effects from the farmers' willingness to deliver biomass, guaranteed collection and the 


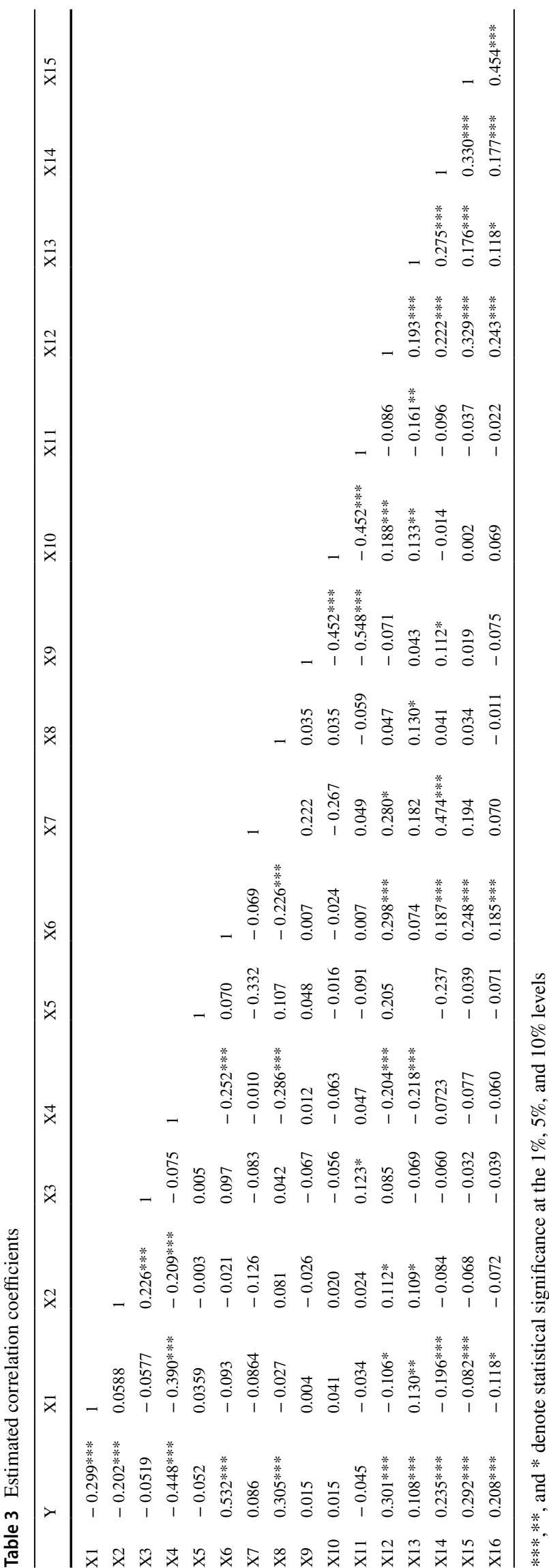

existence of purchase offers from the demand side significantly influence the willingness to sell biomass. Variable X6 (farmers' willingness to deliver biomass) has the largest impact on their interest in selling agricultural biomass (with a very high OR). Variables such as X8 (guaranteed collection) can also be considered crucial, with a significant odds ratio.

\section{Conclusion}

The study shows that the main barrier to biomass market development is the lack of raw energy materials from crop production. The supply-side constraints are caused by low production and the fact that biomass is used mainly in the place of origin on farms. Even if biomass is sold in the region, it is usually for a purpose other than energy needs.

While there is significant energy potential of agricultural biomass in Lodz Province, the survey conducted among farm owners made it possible to identify the following barriers on the supply side of the biomass market: a lack of surplus straw due to its use for farm purposes, significant fragmentation of farms, the distribution of fallow lands and other areas excluded from conventional agricultural production, high costs of developing areas for energy crops, no possibility of selling biomass profitably, no guaranteed systematic collection of raw material, a lack of interest in biomass on the demand side of the market, a lack of organized transport of biomass to recipients, and a lack of knowledge of and access to information on the innovative possibilities of using biomass for energy.

There seem to be more barriers than opportunities regarding the development of the agricultural biomass market in Poland. However, this research made it possible to identify the factors that significantly positively affect farmers' willingness to sell biomass. The estimated odds ratios of these factors are very high, indicating that, ceteris paribus, farmers' willingness to sell biomass increases if the biomass buyer organizes the logistics, if farmers are willing to transport waste biomass themselves and if there is interest on the demand side in the purchase of biomass.

The benefits resulting from the development of distributed energy can be significant. They include reducing transmission losses and increasing energy security on a regional level, as well as the positive impact on the natural environment. For Poland, the greening of the energy sector using waste management remains a major challenge. 


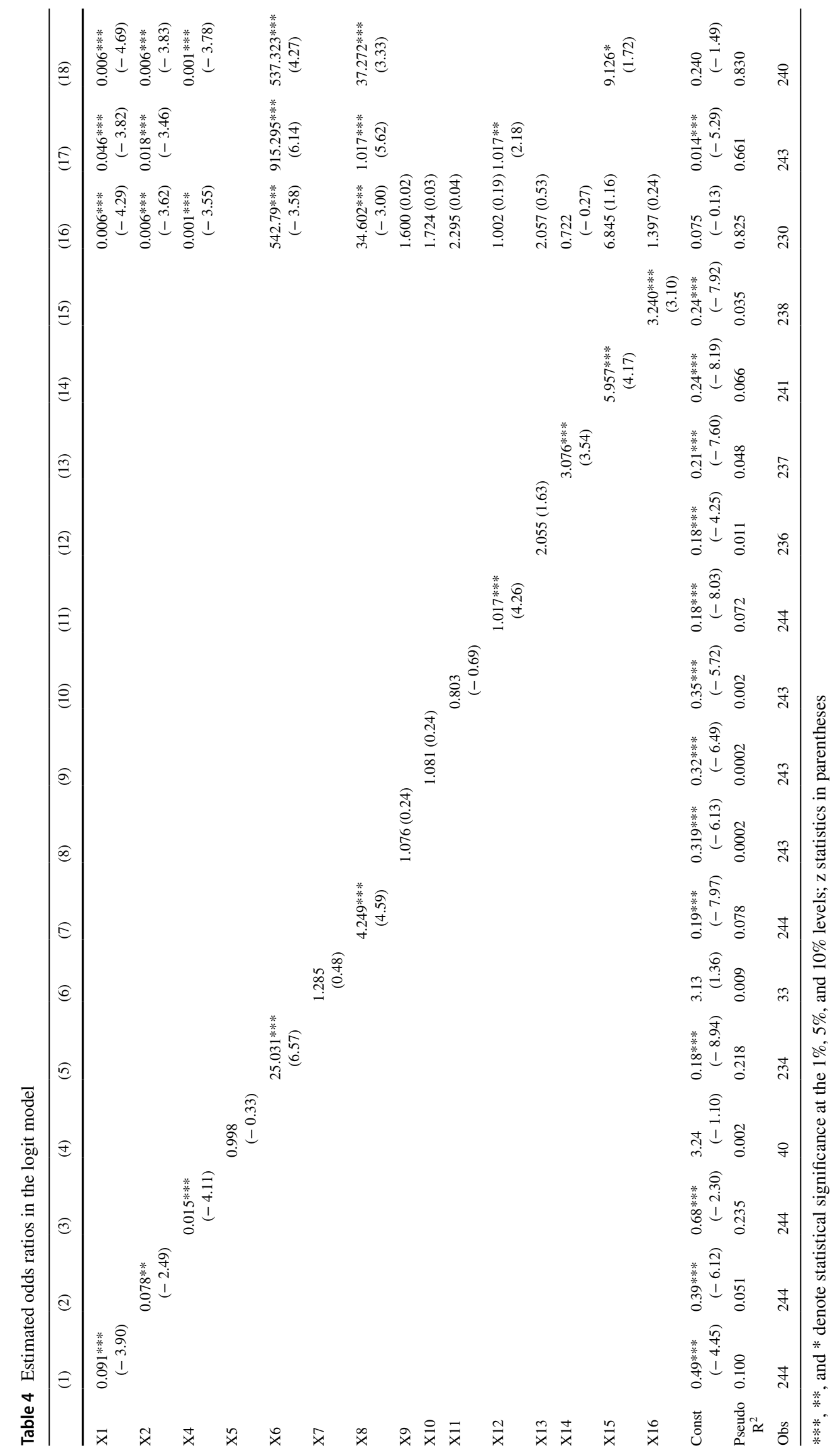


Author contributions SR: data analysis, model design, estimation, writing. NS-W: survey design, data collection and analysis, writing.

Funding No funding.

Data availability The datasets generated and analyzed in the current study are available from the corresponding author on reasonable request. Code availability Not applicable.

Code availability Not applicable.

\section{Declarations}

Conflict of interest The authors declare that they have no conflicts of interest.

Ethical approval Ethics approval was not required for this study. The University of Lodz has no objections to the publication of the results of this study.

Consent to participate The survey on which this study is based was anonymous. Participation in the survey was exclusively voluntary.

Consent for publication Not applicable.

Open Access This article is licensed under a Creative Commons Attribution 4.0 International License, which permits use, sharing, adaptation, distribution and reproduction in any medium or format, as long as you give appropriate credit to the original author(s) and the source, provide a link to the Creative Commons licence, and indicate if changes were made. The images or other third party material in this article are included in the article's Creative Commons licence, unless indicated otherwise in a credit line to the material. If material is not included in the article's Creative Commons licence and your intended use is not permitted by statutory regulation or exceeds the permitted use, you will need to obtain permission directly from the copyright holder. To view a copy of this licence, visit http://creativecommons.org/licenses/by/4.0/.

\section{References}

Altman I, Bergtold J, Sanders DR, Johnson TG (2013) Market development of biomass industries. Agribusiness 29(4):486-496

Barbieri L, Andreola F, Lancellotti I, Taurino R (2013) Management of agricultural biomass wastes: preliminary study on characterization and valorisation in clay matrix bricks. Waste Manage 33(11):2307-2315

Bentsen NS, Felby C (2012) Biomass for energy in the European Union-a review of bioenergy resource assessments. Biotechnol Biofuels 2012:5-25

Bielski S, Marks-Bielska R, Zielińska-Chmielewska A, Romaneckas K, Šarauskis E (2021) Importance of agriculture in creating energy security - a case study of Poland. Energies 14(9):2465

Bórawski P, Bełdycka-Bórawska A, Szymańska EJ, Jankowski KJ, Dubis B, Dunn JW (2019) Development of renewable energy sources market and biofuels in The European Union. J Clean Prod 228:467-484

Budzyński WS, Jankowski KJ, Jarocki M (2015) An analysis of the energy efficiency of winter rapeseed biomass under different farming technologies. A case study of a large-scale farm in Poland. Energy 90:1272-1279

Chang M, Huang W (2018) Hydrothermal biorefinery of spent agricultural biomass into value-added bio-nutrient solution: comparison between greenhouse and field cropping data. Ind Crops Prod 126:186-189

Choi H, Grethe H, Entenmann SK, Wiesmeth M, Blesl M, Wagner M (2019) Potential trade-offs of employing perennial biomass crops for the bioeconomy in the EU by 2050: Impacts on agricultural markets in the EU and the world. GCB Bioenergy 11:483-504

Cintas O, Berndes G, Englund O, Cutz L, Johnsson F (2018) Geospatial supply-demand modeling of biomass residues for co-firing in European coal power plants. GCB Bioenergy 10(11):786-803

de la Rúa C, Lechón Y (2016) An integrated Multi-Regional InputOutput (MRIO) Analysis of miscanthus biomass production in France: socio-economic and climate change consequences. Biomass Bioenerg 94:21-30

European Commission (2012) Analysis of options beyond 20\% GHG emission reductions: member state results. Commission Staff Working Paper 2012 (February)

FAO (2010) Bioenergy and food security: the BEFS analytical framework, environment and natural resources management series no. 16. FAO, Rome

Florkowski WJ, Us A, Klepacka AM (2018) Food waste in rural households support for local biogas production in Lubelskie Voivodship (Poland). Resour Conserv Recycl 136:46-52

García-Torreiro M, López-Abelairas M, Lu-Chau TA, Lema JM (2016) Fungal pretreatment of agricultural residues for bioethanol production. Ind Crops Prod 89:486-492

Goh CS, Aikawa T, Ahl A, Ito K, Kayo C, Kikuchi Y, Saito O (2019) Rethinking sustainable bioenergy development in Japan: decentralised system supported by local forestry biomass. Sustain Sci 15(5):1461-1471

Hosmer DW Jr, Lemeshow S, Sturdivant RX (2013) Applied logistic regression, vol 398. Wiley, Hoboken

Igliński B, Piechota G, Buczkowski R (2015) Development of biomass in polish energy sector: an overview. Clean Technol Environ Policy 17(2):317-329

Li C, Hayes DJ, Jacobs KL (2018) Biomass for bioenergy: Optimal collection mechanisms and pricing when feedstock supply does not equal availability. Energy Econ 76:403-410

Mandova H, Leduc S, Wang C, Wetterlund E, Patrizio P, Gale W, Kraxner F (2018) Possibilities for $\mathrm{CO}_{2}$ emission reduction using biomass in European integrated steel plants. Biomass Bioenerg 115:231-243

Marks-Bielska R, Bielski S, Novikova A, Romaneckas K (2019) Straw stocks as a source of renewable energy. A case study of a district in Poland. Sustainability 11(17):4714

Marks-Bielska R, Bielski S, Pik K, Kurowska K (2020) The importance of renewable energy sources in Poland's energy mix. Energies 13(18):4624

McKendry P (2002) Energy production from biomass (part 1): overview of biomass. Bioresour Technol 83(1):37-46

Niedziółka I, Szpryngiel M, Kraszewicz A, Kachel-Jakubowska M (2011) Assessments of briquetting efficiency and briquette quality produced from selected plant raw materials. Inżynieria Rolnicza 6:149-155 (in Polish)

Panoutsou C (2016) The role of sustainable biomass in the heat market sector for EU27. Wiley Interdiscip Rev Energy Environ 5(4):430-450

Pelkmans L, Van Dael M, Junginger M, Fritsche UR, Diaz-Chavez R, Nabuurs G, Del Campo Colmenar I, Sanchez Gonzalez D, Rutz D, Janssen R (2019) Long-term strategies for sustainable biomass 
imports in European bioenergy markets. Biofuels Bioprod Biorefin 13:388-404

Pinna-Hernández M, Martínez-Soler I, Díaz Villanueva MJ, Acien Fernández FG, Casas López JL (2019) Selection of biomass supply for a gasification process in a solar thermal hybrid plant for the production of electricity. Ind Crops Prod 137:339-346

Ranta T, Rinne S (2006) The profitability of transporting uncomminuted raw materials in Finland. Biomass Bioenerg 30(3):231-237

Roszkowski A (2013) Energy from biomass-effectiveness, efficiency and energetic usability Part 1 . Problemy Inzynierii Rolniczej 21(1):97-124

Searcy E, Hess JR, Tumuluru J, Ovard L, Muth DJ, Trømborg E, Wild M, Deutmeyer M, Nikolaisen L, Ranta T, Hoefnagels R (2014) Optimization of biomass transport and logistics. In: International bioenergy trade. Springer, Dordrecht, pp 103-123

Shen Y, Linville JL, Urgun-Demirtas M, Mintz MM, Snyder SW (2015) An overview of biogas production and utilization at fullscale wastewater treatment plants (WWTPs) in the United States: challenges and opportunities towards energy-neutral WWTPs. Renew Sustain Energy Rev 50:346-362

Siegmeier T, Blumenstein B, Möller D (2015) Farm biogas production in organic agriculture: system implications. Agric Syst 139:196-209
Spinelli R, Pari L, Magagnotti N (2018) New biomass products, smallscale plants and vertical integration as opportunities for rural development. Biomass Bioenerg 115:244-252

Szubska-Włodarczyk N (2018) Agricultural biomass market as an energy raw material. Model and practical approach. Łódź University Press, Łódź (in Polish)

Winden M, Cruze N, Haab T, Bakshi B (2015) Monetized value of the environmental, health and resource externalities of soy biodiesel. Energy Econ 47:18-24

Zawada S (2018) Brown coal-today and in the future. In: International conference on computer aided engineering. Springer, Cham, pp $858-869$

Zyadin A, Natarajan K, Latva-Käyrä P, Igliński B, Iglińska A, Trishkin M, Pelkonen P, Pappinen A (2018) Estimation of surplus biomass potential in southern and central Poland using GIS applications. Renew Sustain Energy Rev 89:204-221

Zyadin A, Natarajan K, Igliński B, Iglińska A, Kaczmarek A, Kajdanek J, Trishkin M, Lisowski A, Dąbrowska M, Pelkonen P, Pappinen A (2021) Farmers' perceptions of the challenges facing the biomass market in Poland, a case study from South and Central Poland. Biofules 12(7): 829-837 